\title{
Oily Wastewater Treatment Using Polyamide Thin Film Composite Membrane Technology
}

\author{
Sarah Elhady ${ }^{1}$, Mohamed Bassyouni ${ }^{2,3, *} \mathbb{0}$, Ramadan A. Mansour ${ }^{4}$, Medhat H. Elzahar ${ }^{5,6}{ }^{\circ}$, \\ Shereen Abdel-Hamid ${ }^{7}$, Yasser Elhenawy ${ }^{8}$ and Mamdou Y. Saleh ${ }^{5,9}$ \\ 1 Public Works Department of Sanitary and Environmental Engineering, the High Institute of Engineering and \\ Technology in New Damietta, New Damietta 34518, Egypt; sarahelhady1990@gmail.com \\ 2 Department of Chemical Engineering, Faculty of Engineering, Port Said University, Port Said 42526, Egypt \\ 3 Materials Science Program, University of Science and Technology, Zewail City of Science and Technology, \\ October Gardens, 6th of October, Giza 12578, Egypt \\ 4 Chemical Engineering Department, Higher Institute of Engineering and Technology, New Damietta, \\ Damietta 34518, Egypt; drramdanelkatep@yahoo.com \\ 5 Sanitary and Environmental Engineering, Faculty of Engineering, Port Said 42526, Egypt; \\ melzahar@yahoo.com (M.H.E.); mamsaleh29@yahoo.com (M.Y.S.) \\ 6 Department of Civil Engineering, Giza Engineering Institute, Elmoneeb, Giza 12511, Egypt \\ 7 Department of Chemical Engineering, Egyptian Academy for Engineering and Advanced Technology, \\ Affiliated to Ministry of Military Production, Al Salam city 3056, Egypt; Shereenahmed@eaeat.edu.eg \\ 8 Department of Mechanical Engineering, Faculty of Engineering, Port Said University, \\ Port Fouad 42526, Egypt; dr_yasser@eng.psu.edu.eg \\ 9 High Institute of Engineering and Technology, El-Manzala, Ad Daqahliyah 35642, Egypt \\ * Correspondence: migb2000@hotmail.com; Tel.: +2-011-596-75357
}

Received: 29 February 2020; Accepted: 26 April 2020; Published: 28 April 2020

check for updates

\begin{abstract}
In this study, polyamide (PA) thin film composite (TFC) reverse osmosis (RO) membrane filtration was used in edible oil wastewater emulsion treatment. The PA-TFC membrane was characterized using mechanical, thermal, chemical, and physical tests. Surface morphology and cross-sections of TFCs were characterized using SEM. The effects of edible oil concentrations, average droplets size, and contact angle on separation efficiency and flux were studied in detail. Purification performance was enhanced using activated carbon as a pre-treatment unit. The performance of the RO unit was assessed by chemical oxygen demand (COD) removal and permeate flux. Oil concentration in wastewater varied between $3000 \mathrm{mg} / \mathrm{L}$ and $6000 \mathrm{mg} / \mathrm{L}$. Oily wastewater showed a higher contact angle $\left(62.9^{\circ}\right)$ than de-ionized water $\left(33^{\circ}\right)$. Experimental results showed that the presence of activated carbon increases the permeation COD removal from $94 \%$ to $99 \%$. The RO membrane filtration coupled with an activated carbon unit of oily wastewater is a convenient hybrid technique for removal of high-concentration edible oil wastewater emulsion up to $99 \%$. Using activated carbon as an adsorption pre-treatment unit improved the permeate flux from $34 \mathrm{~L} / \mathrm{m}^{2} \mathrm{hr}$ to $75 \mathrm{~L} / \mathrm{m}^{2} \mathrm{hr}$.
\end{abstract}

Keywords: edible oil; reverse osmosis; COD; oil droplets size

\section{Introduction}

The increased need for edible oil all over the world has resulted in the development of many edible oil plants, leading to the disposal of huge amounts of wastewater. Palm, olive, soybean, cottonseed, and sunflower are considered the main sources for extracting edible oil [1]. Persistent market research (PMR) has reported that the global oil market value is predicted to increase to 130.3 billion US $\$$ by 2024 , recording a compound annual growth rate of $5.1 \%$. In 2018, global consumption of vegetable oils was 
197.33 million metric tons (MMTs) with an annual production of 203.83 MMTs [2]. Treatment of edible oil industry effluents is considered a major environmental issue. Generally, washing, degumming, de-acidification, deodorization, and neutralization operations are the main sources of oily wastewater discharges. Oily wastewater includes mainly nutrient contents, organic compounds in terms of biological oxygen demand (BOD) and chemical oxygen demand (COD), total suspended solids (TSS), and lipids. Thus, disposal of untreated oily wastewater effluents can result in pollution of soil, water, and air. The waste streams which are emitted without any treatment cause environmental problems such as danger to aquatic life and irreversible damage due to the fact of their high organic concentration and rapid de-oxygenation of water [3,4]. Moreover, wastewater from vegetable edible oil industries contains a higher fraction of slowly biodegradable contents, hence, causing noteworthy environmental issues such as ground and surface water pollution. Accordingly, odor nuisance, water color, and low soil quality can be addressed and reported, taking into consideration environmental issues and human health. Therefore, it is necessary to treat oily wastewater effluents to meet environmental regulations and standards.

Physical and chemical oily wastewater characteristics depend mainly on the type of edible oil industry where high organic and inorganic pollutants are varied. Numerous methods have been applied for treating pollution in edible oil wastewater [5-9]. Traditional techniques, such as coagulation/flocculation, adsorption, dissolved air flotation (DAF), are normally insufficiently effective to solve the problem, particularly when the oil particles are finely dispersed [10-13]. Recently, membrane separation and filtration of oily wastewater have gained significant attention because of its ability to remove most chemicals and microbic contents [14]. It is worth mentioning that the quality of the treated water is mostly consistent with the influent variations. Additionally, it can be used in recycling of selected waste streams for different applications. Membrane technology is used to obtain stable permeate and rejected stream quality which can be reused and recycled in desired applications [15-20]. Microfiltration and ultrafiltration processes to treat oily wastewater have previously been reported [21,22]. Masoudnia et al. (2015) employed microfiltration (MF) using polyvinylidene fluoride (PVDF) membrane for wastewater from the edible oil industry [23]. However, it was found that membrane performance decreased with time due to the fact of fouling issues [24]. Membrane fouling may include pore blocking, chemical degradation, and cake formation on the surface of membrane due to the presence of microbes or impurities gathering in the form of inorganic and organic matters. Additionally, this process leads to shorter life expectancy of the membrane. Polymeric and ceramic membranes have been employed in oily wastewater treatment [25,26]. Most organic membranes offer several benefits such as low cost and high removal efficiency. However, they cannot withstand the high temperature, pressure, and fouling that limit the membrane regeneration [27]. Membrane fouling as a result of the accumulation of impurities has always been a challenge and limits membrane applications [28]. Chemicals to clean fouling increase the cost and energy demand. Coupling of feed water pretreatment to the membrane unit is a possible solution to reduce the fouling issue [29]. Thus, in order to decrease membrane fouling, pre-treatment of the unit is often preferred (including coagulation, adsorption, filtration, or oxidation) [30-32]. It is supposed that oil droplets and colloids are destabilized and gathered, forming larger flocs within coagulation pretreatment units which can be removed easily by membrane filtration [33].

Modification of the membrane structure to be more hydrophilic is another solution to mitigate fouling formation [14]. Various membrane treatment types (namely, UF, Nanofiltration (NF) anaerobic membrane system, $\mathrm{RO}$, and MF) have been reported as oily wastewater treatments [34]. The COD and turbidity measurements of permeate stream must be measured in order to estimate the optimal conditions for oily wastewater treatment [35]. Šereš et al. (2016) have successfully removed up to $99 \%$ of turbidity and $85 \%$ of COD from oily wastewater using microfiltration ceramic membrane. Its pore size (200 nm) and transmembrane pressure operated up to 3 bar [36]. Reverse osmosis is able to treat oily wastewater. It is generally used to avoid membrane fouling problems [34]. Stoller et al. (2016) used hybridizing membrane systems, including UF, NF, and RO, for the treatment of olive oil processing 
wastewater [37]. Azmi et al. studied a UF and RO hybrid membrane system on palm oil/water emulsion. Removal of BOD and turbidity up to $98.9 \%$ and $99 \%$, respectively, were obtained [38]. In another study, the same research team used sand filtration and coagulation/flocculation before the membrane unit for oily wastewater treatment [39]. A remarkable reduction in COD (95\%) and BOD $(95 \%)$ was recorded. In this study, an activated carbon adsorption unit was used for pretreatment. The present investigation aimed to identify the optimum conditions allowed for the permeate stream suitable for recycling or to be discharged into water sewage with no risk of toxicity to the ecosystem. Coupling of the adsorption unit to $\mathrm{RO}$ was investigated in a hybrid mode. The treatment processes were compared based on their efficiency in COD and turbidity removals. It was concluded that this coupling of treatment units was able to purify edible oil wastewater emulsion and treated water to meet standards.

\section{Materials and Methods}

Polyoxyethylene sorbatin monolaurate "Tween 20" $\left(\mathrm{C}_{58} \mathrm{H}_{11} \mathrm{O}_{26}, \mathrm{MWt}=1227.72 \mathrm{~g} / \mathrm{mol}\right)$ was used as a surfactant. Oily wastewater was synthesized by mixing 5 mLof soybean oil and $1 \mathrm{~L}$ of distilled water in the presence $1 \mathrm{~mL}$ of Tween 20 . The oily wastewater emulsion was mixed mechanically for $3.5 \mathrm{~h}$ at a mixing rate of $300 \mathrm{rpm}$. The stability of the oily wastewater emulsion was observed after $24 \mathrm{~h}$. The mixture showed a uniform and stable white emulsion. The PA-TFC RO membrane in a spiral wound structure was investigated. The Membrane model (TW 30-1812-75) was installed-length: 0.26; diameter: $0.05 \mathrm{~m}$; maximum service temperature and pressure: $45^{\circ} \mathrm{C}$ and $1.034 \mathrm{MPa}$, respectively; applied pressure: $0.86 \mathrm{MPa}$; and allowable range of $\mathrm{pH}: 2$ to 10 . The pores' size ranged from $0.67 \mathrm{~nm}$ to $0.78 \mathrm{~nm}$ [40]. The maximum flow rate of was $0.0076 \mathrm{~m}^{3} / \mathrm{min}$. The granular activated carbon (GAC) filter was installed as an adsorption pretreatment unit. The column dimensions were $63.5 \mathrm{~mm}$ and (height) $254 \mathrm{~mm}$. The GAC filter was fixed to reduce total suspended solids and chemicals resulting in undesired tastes and odors and volatile organic chemicals (VOCs). The GAC is capable of delivering up to $0.0038 \mathrm{~m}^{3}$ per minute of treated water. A high-pressure pump (PKM60) with dimensions $0.0254 \mathrm{~m} \times$ $0.0254 \mathrm{~m}, \mathrm{Q}_{\max }$ " $0.04 \mathrm{~m}^{3} / \mathrm{min}$ ", and "2850 $\mathrm{rpm}$ " was installed to pump the water-oil emulsion across the membrane surface. An analysis of oil wastewater and treated water was conducted in terms of turbidity, oil and grease, and COD.

\subsection{Measuring and Analysis}

\subsubsection{Chemical Oxygen Demand (COD)}

Chemical oxygen demand for all oily wastewater samples (feed, permeate, and rejection) was measured by COD photometer (LaMotte, Chestertown, MD, USA). Sample $(0.2 \mathrm{~mL})$ was added into digested solution (High range: $200-15,000 \mathrm{mg} / \mathrm{L}$ ) consisting of a strong oxidizing agent (potassium dichromate), mercuric sulfate, and sulfuric acid. The water mixture was then heated for $120 \mathrm{~min}$ in a COD heater at $150^{\circ} \mathrm{C}$. By the end of oxidation, the COD was measured using a spectrophotometer.

\subsubsection{Turbidity}

The samples of feed, permeate, and rejection were analyzed for total suspended solids in terms of turbidity using a turbidity meter (Lovibond meter, Lovibond company, Sarasota, FL, USA) expressed as nephelometric turbidity units (NTUs).

\subsubsection{Thermogravimetric Analysis (TGA)}

Thermal stability of polyester support, polysulfone, and polyamide layers were characterized using TGA (TGA Q500 V20.10 Build 36, TA Company, Tokyo, Japan). Thermogravimetric analysis is considered a proper method to quantitatively examine the thermal stability of polymeric membrane materials. 


\subsubsection{Fourier-Transform Infrared Spectroscopy (FTIR)}

The membrane model (TW 30-1812-75) was investigated using FTIR analysis (Avatar 370 Nicolet Spectrometer, Madison, CA, USA) to characterize and identify chemical bonds.

\subsubsection{Scanning Electron Microscopy (SEM)}

The thin film composite RO membrane was freeze-fractured and gold coated using an S150A SPUTTER COATER SEM (Edwards High Vacuum $=7.5 \mathrm{mbar}$ ). Surface morphology and cross-sections of TFC membranes were investigated using scanning electron microscopy (SEM, Quanta 250 FEG, FEI Company, Tokyo, Japan).

\subsubsection{Mechanical Testing}

The strength of the RO membrane was measured using a (Tinius Olsen H25KS, Shanghai, China) tensile instrument by providing load coaxial style.

\subsubsection{Average oil Particle Size}

The size distribution of oil droplets in the oily wastewater feed was determined using a laser particle size analyzer (Nicomp Nano size, 380 ZLS, Santabarbara, CA, USA).

\subsubsection{Dynamic Wetting}

Each sample was cut to a size of $10 \mathrm{~mm} \times 50 \mathrm{~mm}$ with sharp scissors. The TFC-PA specimen was immersed into oily wastewater and water samples. The weight of the absorbed water was measured. The dynamic water absorption was plotted versus time.

\subsubsection{Contact Angle}

To study the effect of edible oil on the hydrophobicity of the PA-THF RO membrane, the surface contact angle of the membrane was measured based on the sessile drop method via a contact angle measuring instrument (OCA 15EC contact angle model, GmbH, Filderstadt, Germany). The reported results were the average contact angle of deionized water droplets and oily wastewater at five different locations on each sample.

\subsubsection{Oil and Grease}

The oil concentration was determined using the hexane extraction gravimetric method. One hundred and twenty-five milliliters of oily wastewater samples were added to ethanol $(20 \mathrm{~mL})$ and sulfuric acid $(20 \mathrm{~mL})$. Mixtures were well shaken in a separation funnel. After fifteen minutes, two layers were separated, and the supernatant layer containing the oil (organic layer) was collected. The weight $(\mathrm{wt})$ of the beaker before and after separation was recorded. Then, the oil concentration was calculated as given in Equation (1).

$$
\text { Oil concentration }=\frac{\mathrm{wt}(\mathrm{mg})}{\text { volume of sample }(\mathrm{ml}) \times 1000}
$$

\subsection{Experimental Setup and Operation}

The tank, made from acrylic for mixing the water-oil emulsion, is shown in Figure 1. The tank's dimensions were $0.4 \mathrm{~m}$ in diameter and $0.7 \mathrm{~m}$ in height with a total volume of $0.05 \mathrm{~m}^{3}$ and a rotational speed of $300 \mathrm{rpm}$ for the stainless-steel mixer. 

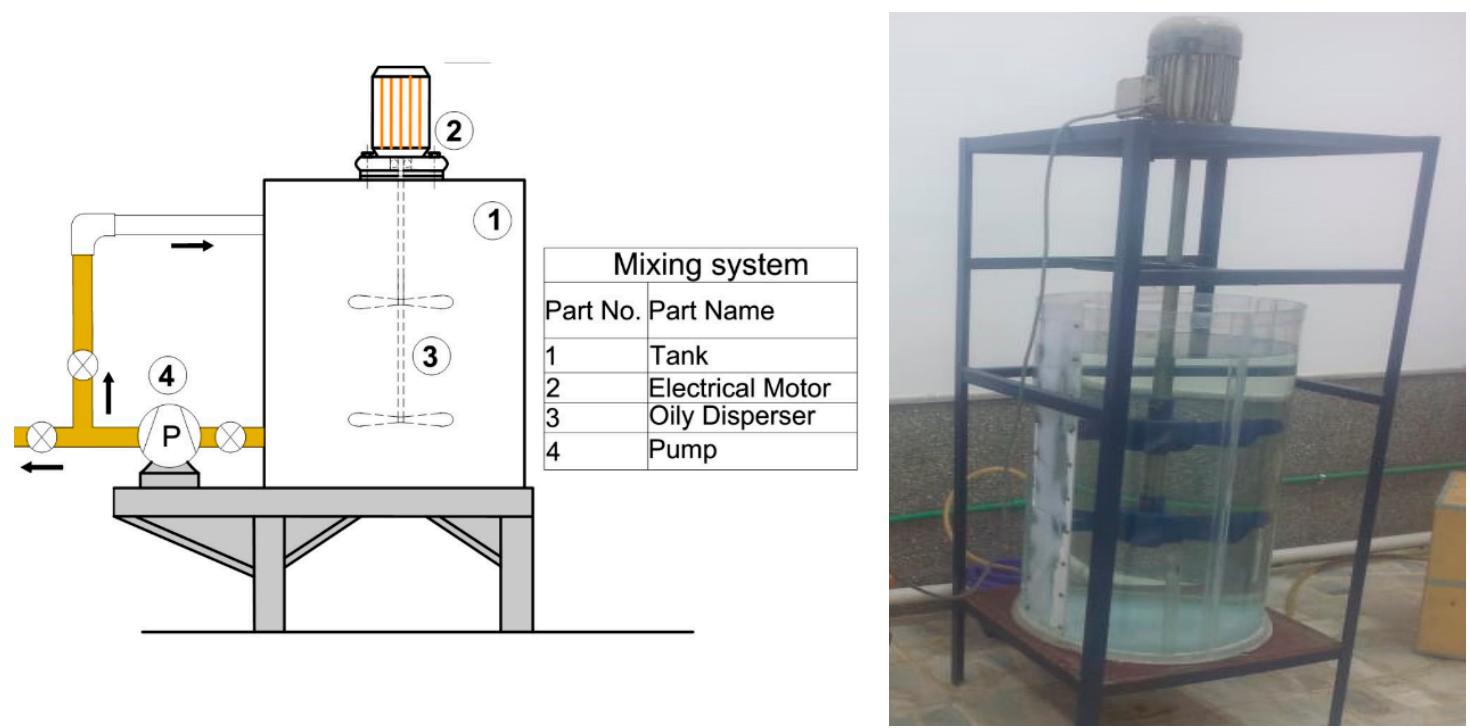

Figure 1. Mixing tank for preparation of nano-emulsion oil in water.

Figure 2a shows the schematic diagram of the PA-TFC RO membrane filtration unit and the facilities. The membrane was washed using de-ionized water for fifteen minutes before the treatment process to ensure that the $\mathrm{RO}$ had reached maximum force. The synthetic wastewater/oil emulsion was fed in mechanically stirred tanks, $0.04 \mathrm{~m}^{3}$, in the presence of surfactant (Tween 20). The oily wastewater was pumped to the $\mathrm{RO}$ unit under a constant pressure of $8.5 \mathrm{bar}$. The oil concentration in wastewater varied from $3 \mathrm{~g} / \mathrm{L}$ to $6 \mathrm{~g} / \mathrm{L}$. The treated water was collected from the $\mathrm{RO}$ unit, determined by collected permeate water in vessel. The permeate flow rate was measured regularly to calculate flux. The permeate, rejected, and feed water contents were tested for COD, oil and grease, and turbidity. The rejected wastewater stream was analyzed to determine oil content in the oily wastewater. To control the membrane fouling, a pre-treatment adsorption unit of activated carbon was installed. In the feed pretreatment unit, adsorption GAC was applied to remove suspended solids and organic constituents. The pretreatment process plays a crucial role for treatment process of high concentration edible oil wastewater in oil industries that would block the membrane and reduce its lifetime. A process flow diagram (PFD) of the pre-adsorption unit and membrane filtration process are shown in Figure $2 b$. After oily wastewater treatment using the hybrid system (i.e., GAC and RO membrane), the treated water sample was tested for possible irrigation or discharge into the sewage network. The oil contents were determined in the rejected stream for recycling highly concentrated oily wastewater streams in the production of soap as a step towards a zero discharge system [41]. Turbidity and COD were measured in each process to study the efficiency of oil removal. 

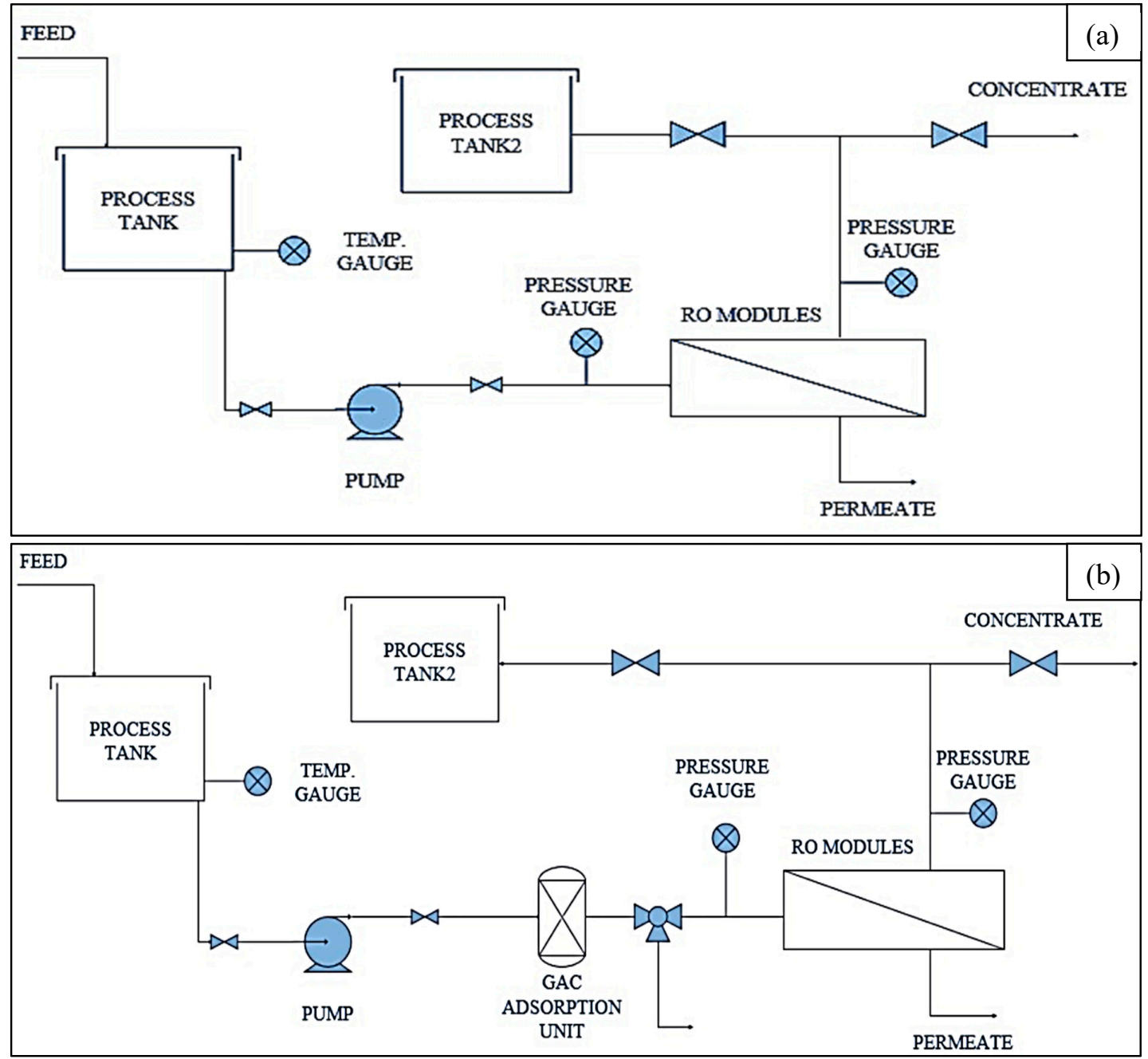

Figure 2. The diagram of an edible oil wastewater treatment unit using (a) a polyamide (PA) thin film composite (TFC) reverse osmosis (RO) membrane (b) pretreatment unit with a powder carbon filter.

Percentage Oil Rejection and Flux

In the RO membrane unit, the separation efficiency was determined in terms of rejection (\%) of COD, turbidity or oil and grease as given in Equation (2) [5]:

$$
\mathrm{R}(\%)=\frac{\mathrm{CF}-\mathrm{CP}}{\mathrm{CF}} \times 100
$$

The $\mathrm{CP}$ is the concentration of oil in permeate stream; $\mathrm{CF}$ is the oil concentration in the feed.

The water flux $(\mathrm{J} \omega)$ is the volume of permeate $(\mathrm{V})$ that is collected per unit membrane surface area (a) per unit time (t). Water flux is determined as given in Equation (3):

$$
\mathrm{J} \omega=\frac{\mathrm{V}}{\mathrm{a} \times \mathrm{t}}
$$




\section{Results and Discussion}

\subsection{Membrane Characterization}

\subsubsection{Surface Morphology}

Polyamide thin film composite contains three layers of thin film PA, polysulfone, and a supported layer of polyester. The SEM images of the TFC membrane were investigated before and after oily wastewater treatment to analyze microscopic structure of the membrane. Cross-sectional images of the TFC were taken after the cutting with freeze-fracturing. Figure 3a shows cross-sectional images which show the RO polyamide membrane consisting of three layers: a thin selective layer on the upper surface $(0.22 \mu \mathrm{m})$, a microporous interlayer (about $17.21 \mu \mathrm{m})$, and polyester acting as structural support $(92.61 \mu \mathrm{m})$. The SEM micrographs of pristine membrane are shown in Figure 3b. Membrane surface morphology after wastewater treatment is shown in Figure 3c. It was found that oil droplets absorbed on the surface of the TFC membrane. In the absence of the GAC unit, most of the membrane pores were blocked, resulting in a decrease in membrane flux. Zhao et al. (2015) reported similar results on polyvinylchloride ultrafiltration membranes blocking in oily wastewater treatment [42].
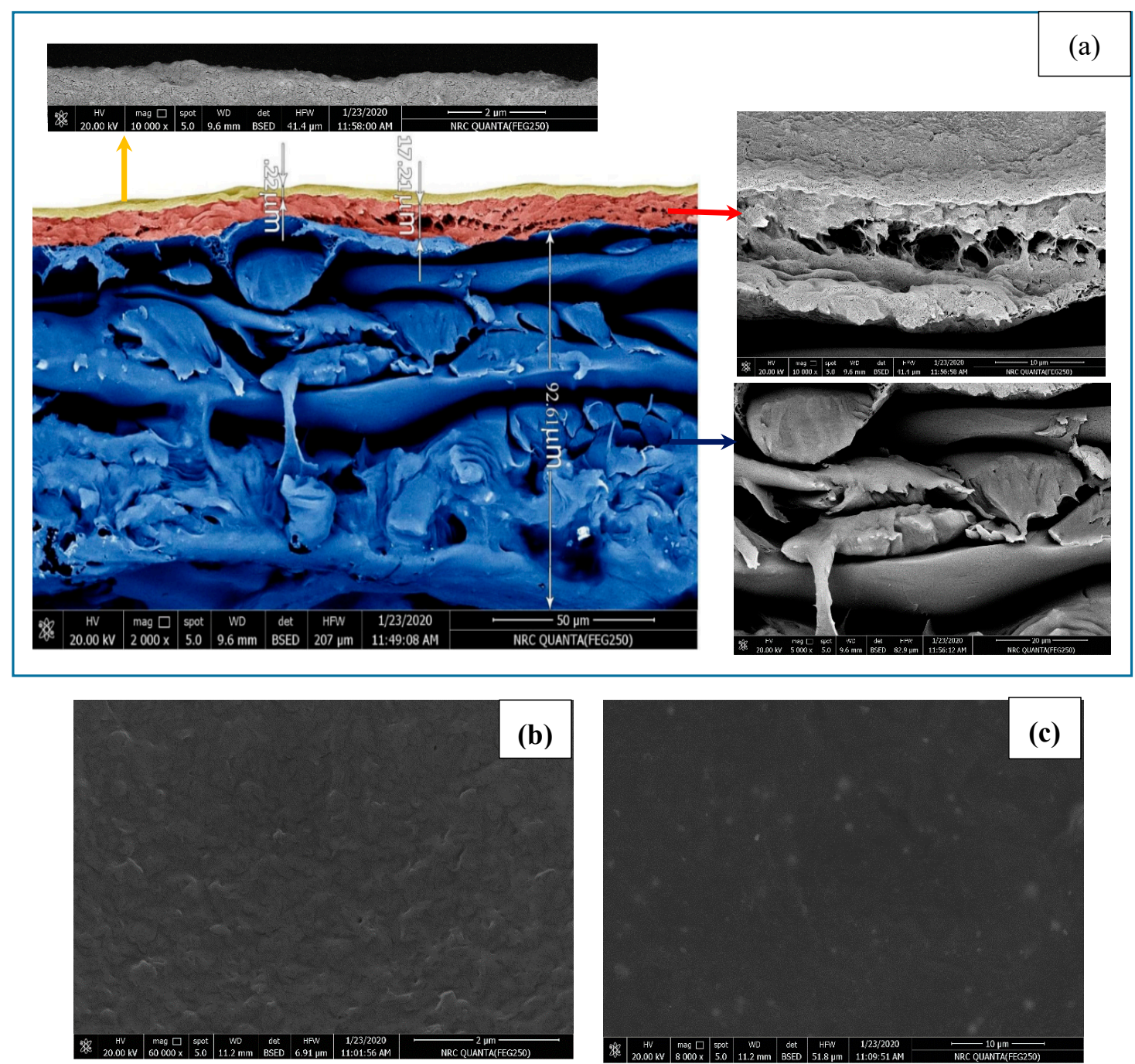

Figure 3. (a) Cross-section of an $\mathrm{RO}$ membrane, (b) surface morphology before oily wastewater treatment, and (c) surface morphology after oily wastewater treatment. 


\subsubsection{Contact Angle}

Hydrophilicity is one of the most crucial parameters that influences the permeability and antifouling process of the membrane surface. A low contact angle refers to the high hydrophilicity of the surface. Contact angles of the TFC membrane were measured using advancing contact angle methods. As shown in Figure 4, the contact angle of water on the surface was $33^{\circ}$, while the average contact angle of oily wastewater on the membrane surface was $62.9^{\circ}$. These results suggest that the membrane in water was more hydrophilic than oil.
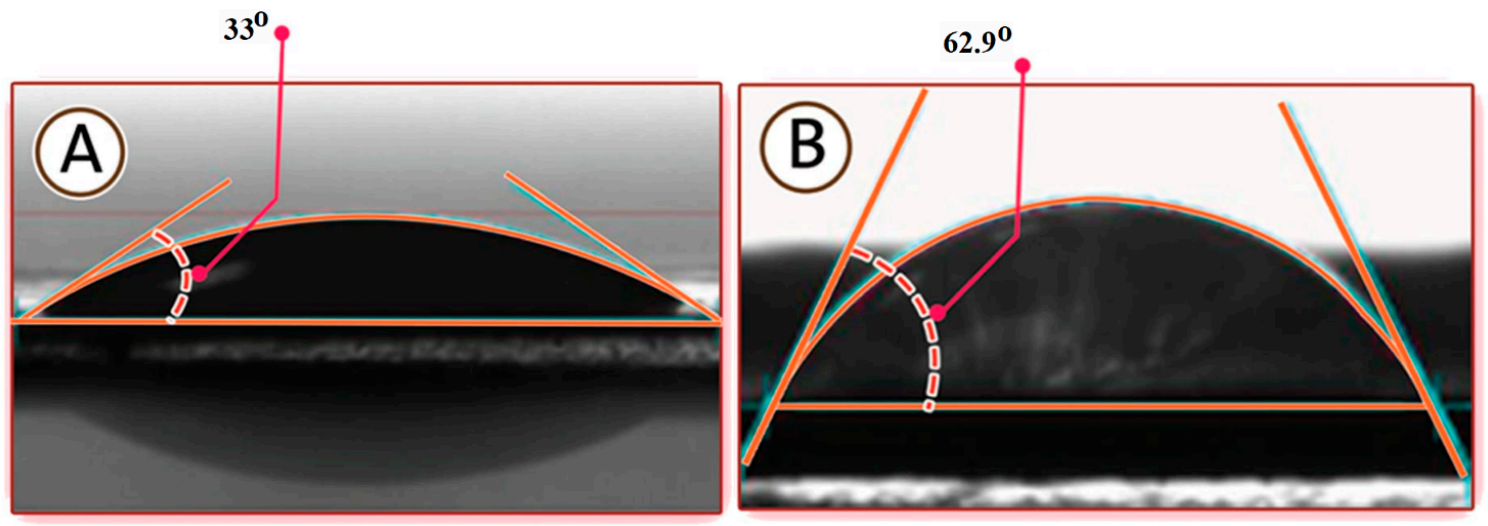

Figure 4. Contact angles of (A) water and (B) oil on the membrane surface.

\subsubsection{Mechanical Test}

Figure 5 shows the results of the stress-strain behavior of the TFC membrane. The tensile strength was found to be $52 \mathrm{MPa}$, and the Young's modulus was $1000 \mathrm{MPa}$. The mechanical testing results are listed in Table 1.

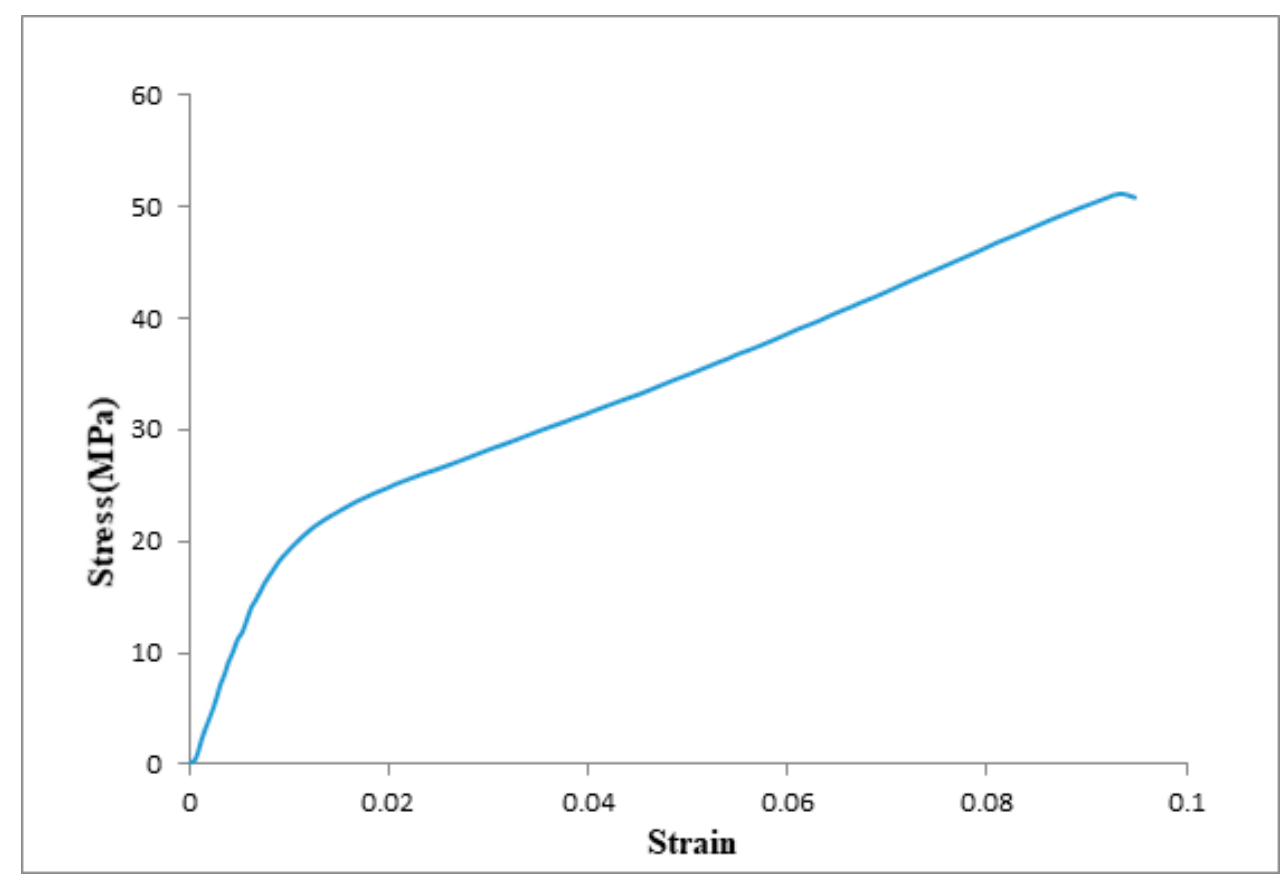

Figure 5. The stress-strain curve for PA-TFC reverse osmosis membrane. 
Table 1. Mechanical properties of polyamide membrane.

\begin{tabular}{cc}
\hline Property & Polyamide Thin Film Composite \\
\hline Tensile strength, $\mathrm{MPa}$ & 51.15 \\
Young's modulus, $\mathrm{MPa}$ & 1000 \\
\hline
\end{tabular}

\subsubsection{Thermogravimetric Analysis (TGA)}

Thermogravimetric analysis (TGA) of the reverse osmosis membrane was performed under nitrogen atmosphere as shown in Figure 6. Four weight-loss stages can be observed in the TGA curve. Weight loss at an average temperature $100{ }^{\circ} \mathrm{C}$ can be attributed to water loss. The second stage at an average temperature $304-551{ }^{\circ} \mathrm{C}$ refers to the thermal degradation range of the supported polyester layer. The third stage at an average temperature $450-550{ }^{\circ} \mathrm{C}$ can be attributed to polyamide loss. The fourth stage shows the weight loss of the polysulfone layer, starting from $590^{\circ} \mathrm{C}$.

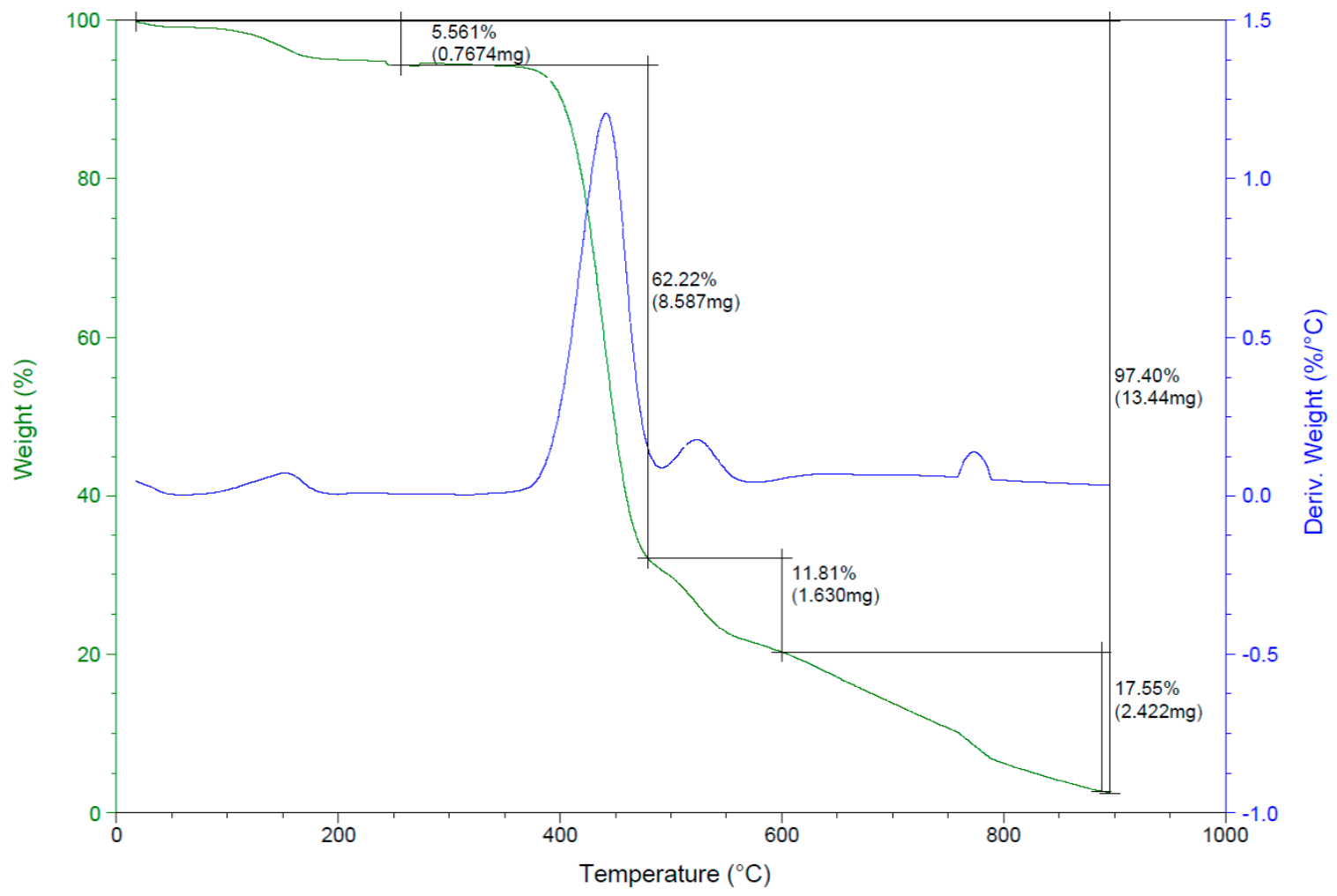

Figure 6. TGA for the reverse osmosis membrane.

\subsubsection{Fourier Transform-Infrared Spectroscopy FTIR}

The FTIR was used to analyze the chemical composition of the top surface of membrane (PA), and PSF and polyester-supported layer. The infrared spectra of TFC membrane showed the main characteristic peaks of PA layer and polysulfone-supporting layer as shown in Figure 7 and listed in Table 2. 


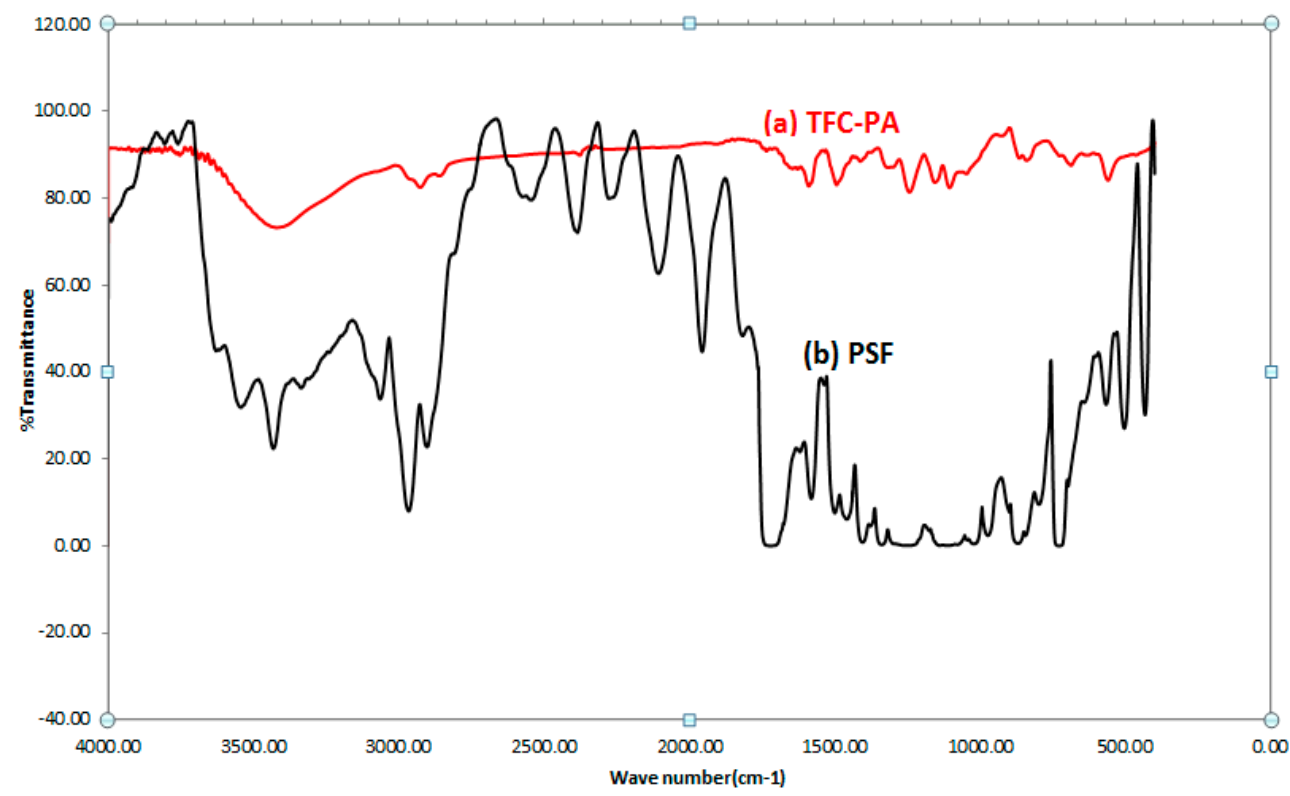

Figure 7. FTIR spectra for TFC-PA membrane and polysulfone (PSF) support layer.

Table 2. The main characteristic peaks for PA and PSF.

\begin{tabular}{|c|c|c|c|}
\hline \multicolumn{2}{|r|}{ PA } & \multicolumn{2}{|r|}{ PSF } \\
\hline Range $\left(\mathrm{cm}^{-1}\right)$ & Assignment & Range $\left(\mathrm{cm}^{-1}\right)$ & Assignment \\
\hline 840.39 & aromatic hydrogen, isolated & 727.89 & Aromatic hydrogen \\
\hline 1105.05 & 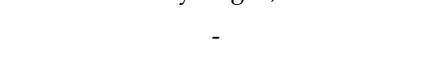 & 870.12 & $\begin{array}{l}\text { Hydrogen deformation of } \\
\text { para-substituted phenyl groups. }\end{array}$ \\
\hline 1155.67 & $\mathrm{C}-\mathrm{N}$ bending & 1248.53 & $\begin{array}{l}\mathrm{C}-\mathrm{O}-\mathrm{C} \text { asymmetric stretching } \\
\text { vibration of the aryl-O-aryl group } \\
\text { Aromatic in-plane ring bend }\end{array}$ \\
\hline 1242.98 & $\mathrm{C}-\mathrm{N}$ bending & 1581.03 & $\begin{array}{l}\text { stretching } \\
\text { vibration }\end{array}$ \\
\hline 1493.59 & Aromatic ring breathing & 3064.54 & $\mathrm{O}-\mathrm{H}$ aromatic stretching \\
\hline 1590.13 & $\begin{array}{l}\mathrm{C}=\mathrm{O} \text { band of an amide group, } \mathrm{C}-\mathrm{N} \\
\text { stretching, and } \mathrm{C}-\mathrm{N}-\mathrm{C} \text { deformation } \\
\text { vibration in a secondary amide group }\end{array}$ & - & - the \\
\hline 3420.93 & $\mathrm{~N}-\mathrm{H}($ and $\mathrm{O}-\mathrm{H})$ & - & - \\
\hline 3647.56 & $\mathrm{O}-\mathrm{H}$ aromatic stretching bands & - & - \\
\hline
\end{tabular}

\subsection{Effect of Oil Particle Size on Separation Efficiency}

Oil particles that are captured on the PA-TFC RO membrane surface affect separation efficiency across membrane filtration. The PA-TFC RO membrane's capacity may vary depending on the particle size variation in the oily wastewater as shown in Figure 8. The distribution of oil droplets' size was measured for six samples of emulsion to study the effect of oil particle size on the separation efficiency. It was found that the separation performance improves as the oil particles' sizes increase. This can be attributed to the coalescence of oil particle droplets where these are retained on thin film membrane. Thus, rejection efficiency increased from $94 \%$ to $99 \%$ with the increase of oil concentration as well as the average droplet size. Similar trends were observed by Chakrabarty et al. [43] and Mittal et al. [44].

\subsection{Dynamic Wetting}

All membranes demonstrated water absorption curves that rose sharply within $20 \mathrm{~s}$. Further immersion occurred after $20 \mathrm{~s}$ up to $90 \mathrm{~s}$, inducing a plateau in all curves. Early in the immersion period, instantaneous water absorption was observed for all membranes. After $20 \mathrm{~s}$ all curves plateaued, showing that all membranes could only absorb a certain number of water molecules. This observation confirms the hydrophilic behavior of the TFC membrane. The absorption curve of the TFC membrane 
can be seen in Figure 9. Oil contents considerably decreased the water absorption properties of the RO membrane. This can be attributed to the higher contact angles.
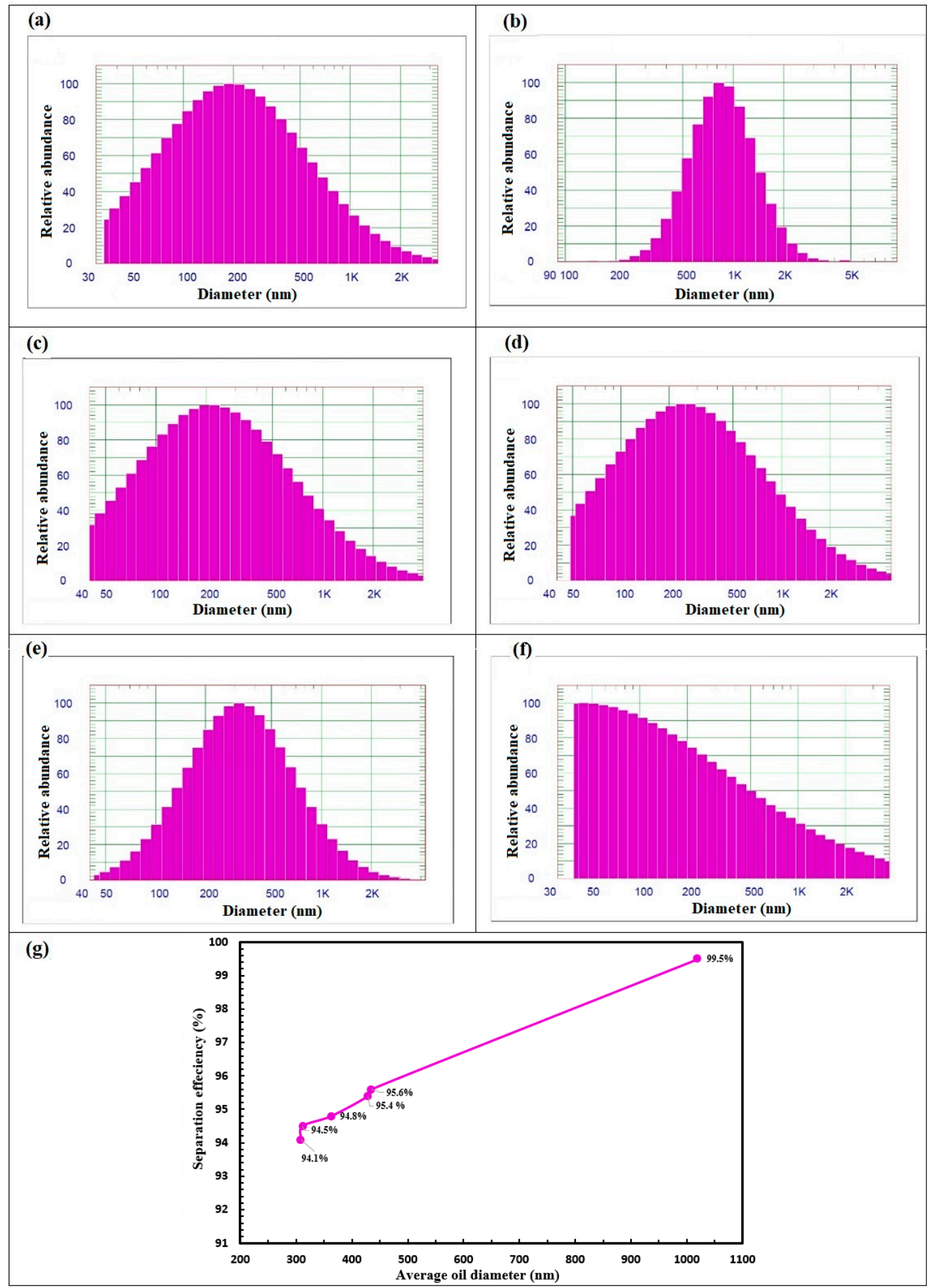

Figure 8. Effect of oil particle size on separation efficiency, average oil droplet size (a-f) and (g) effect of average oil droplet size on membrane separation. 


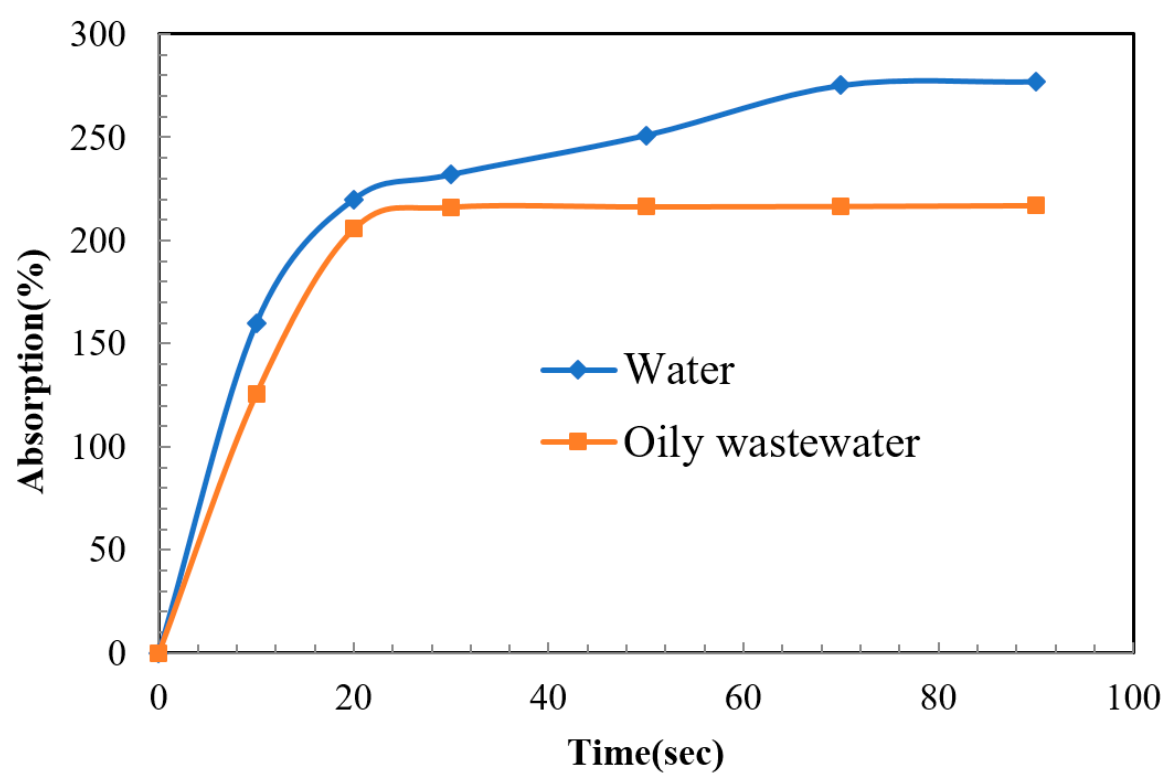

Figure 9. Water and oily wastewater absorption of the thin film composite membrane.

\subsection{Effect of Time on Permeate Flux}

The fluxes of permeate oily wastewater were taken every $50 \mathrm{~min}$, starting from $5 \mathrm{~min}$. Figure 10 shows that the initial flux in case of $\mathrm{RO}$ and $\mathrm{RO}$ and adsorption pretreatment hybrid system were $34 \mathrm{~L} / \mathrm{m}^{2} \cdot \mathrm{h}$ and $75 \mathrm{~L} / \mathrm{m}^{2} \cdot \mathrm{h}$, respectively. The initial flux was the maximum value at constant pressure 8.5 bar. This phenomenon can be attributed to the lowest value of mass transfer resistance at the beginning. At the membrane surface, permeate flow rate reduces with time and concentration polarization increases. A decrease in flux was recorded as a result of increased mass transfer resistance, so fouling is often considered in the form of decreasing permeate flux over time [45-49]. Membrane blocking leads to a decrease in membrane performance because of suspended solids accumulating on the outer layer. This could be observed in the RO unit without an adsorption unit. Differences in fouling behavior between the oily wastewater treatment using $\mathrm{RO}$ and the $\mathrm{RO}$ hybrid system were expected as a result of the differences in the rate of fouling.

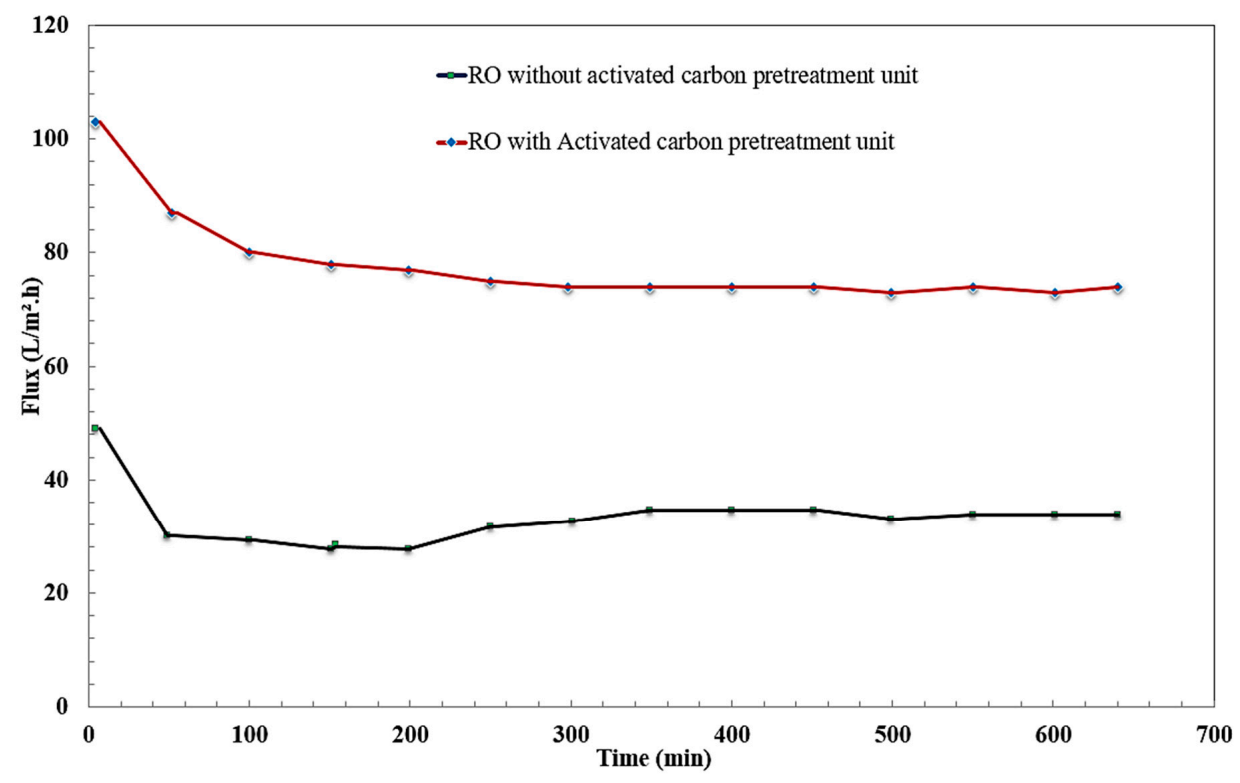

Figure 10. Effect of time separation on flux. 


\subsection{Effect of Oil Concentration on Separation Efficiency}

The effect of the oil concentration on the separation performance was determined at a constant pressure of $0.85 \mathrm{MPa}$, as listed in Table 3, which describes the maximum concentration of suspended solid in terms of turbidity and COD removal. The results are presented in Figures 11 and 12, showing that the oil removal increases with an increase in feed concentration. Separation efficiency improves with the increase in oil concentration which can be attributed to the formation of larger oil droplets. Furthermore, oil droplets separated by the membrane form a gel layer on the membrane surface [43]. Thus, removal can be improved. However, the flux decreases in the absence of an adsorption pretreatment unit. The average removal of oil in terms of COD reached $97.4 \%$. The performance of membrane showed high COD removal. The COD of the permeate stream was within the allowable levels (1100 ppm) for the discharge of wastewater into sewage networks.

Table 3. Effect of oil concentration on the properties of treated water.

\begin{tabular}{ccccc}
\hline $\begin{array}{c}\text { Feed COD } \\
\text { Concentration } \\
(\mathbf{m g} / \mathbf{L})\end{array}$ & $\begin{array}{c}\text { Permeate COD } \\
\text { Concentration } \\
\mathbf{( m g / L )}\end{array}$ & $\begin{array}{c}\text { Separation } \\
\text { Efficiency } \%\end{array}$ & $\begin{array}{c}\text { Feed Turbidity } \\
\text { (NTUs) }\end{array}$ & $\begin{array}{c}\text { Permeate } \\
\text { Turbidity (NTUs) }\end{array}$ \\
\hline 5653 & 386 & 97.4 & 990 & 1.28 \\
4343 & 490 & 95.35 & 980 & 1.22 \\
3591 & 528 & 94.53 & 870 & 1.84 \\
3299 & 521 & 94.12 & 850 & 1.6 \\
\hline
\end{tabular}

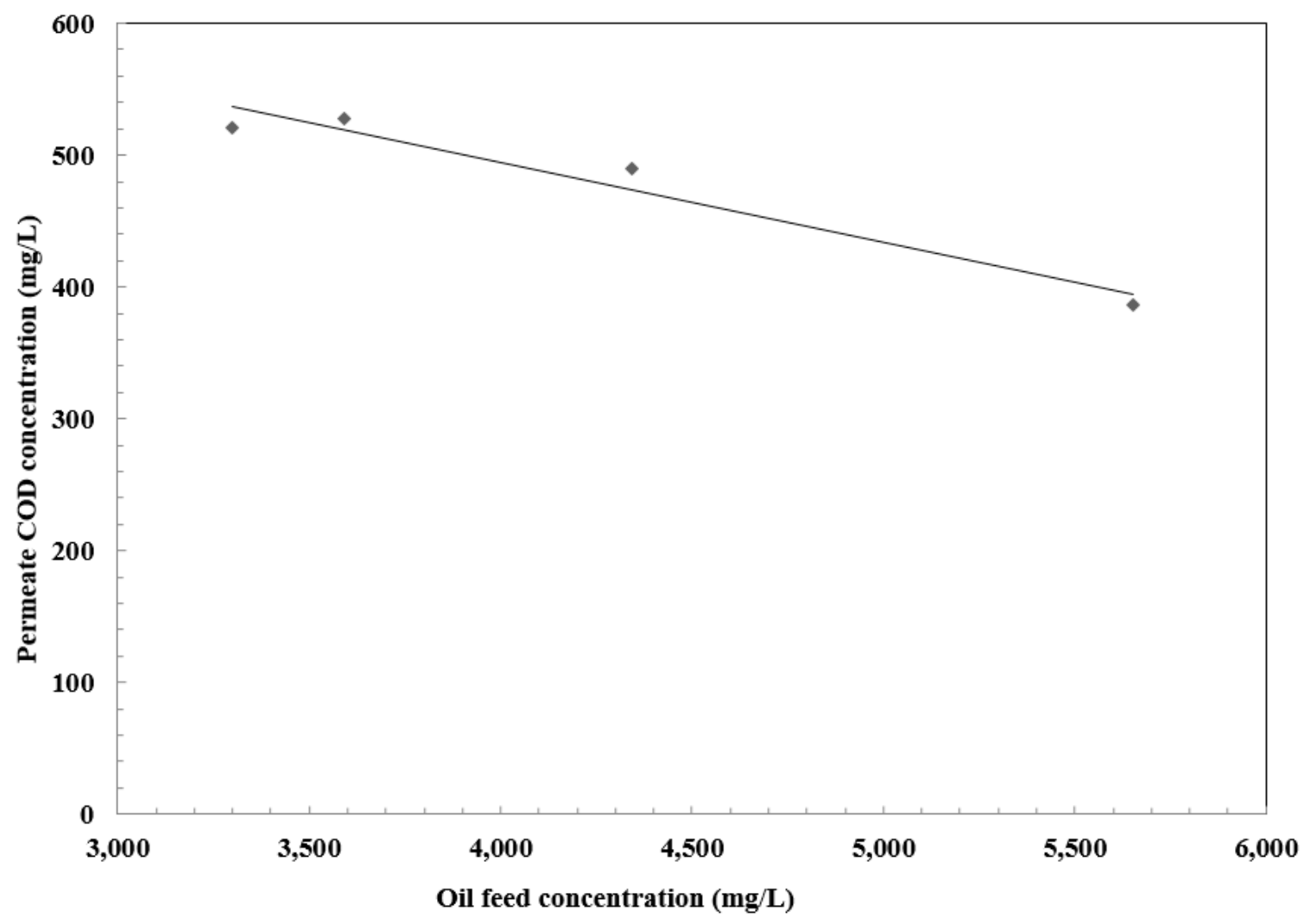

Figure 11. Effect of feed concentration on permeate COD. 


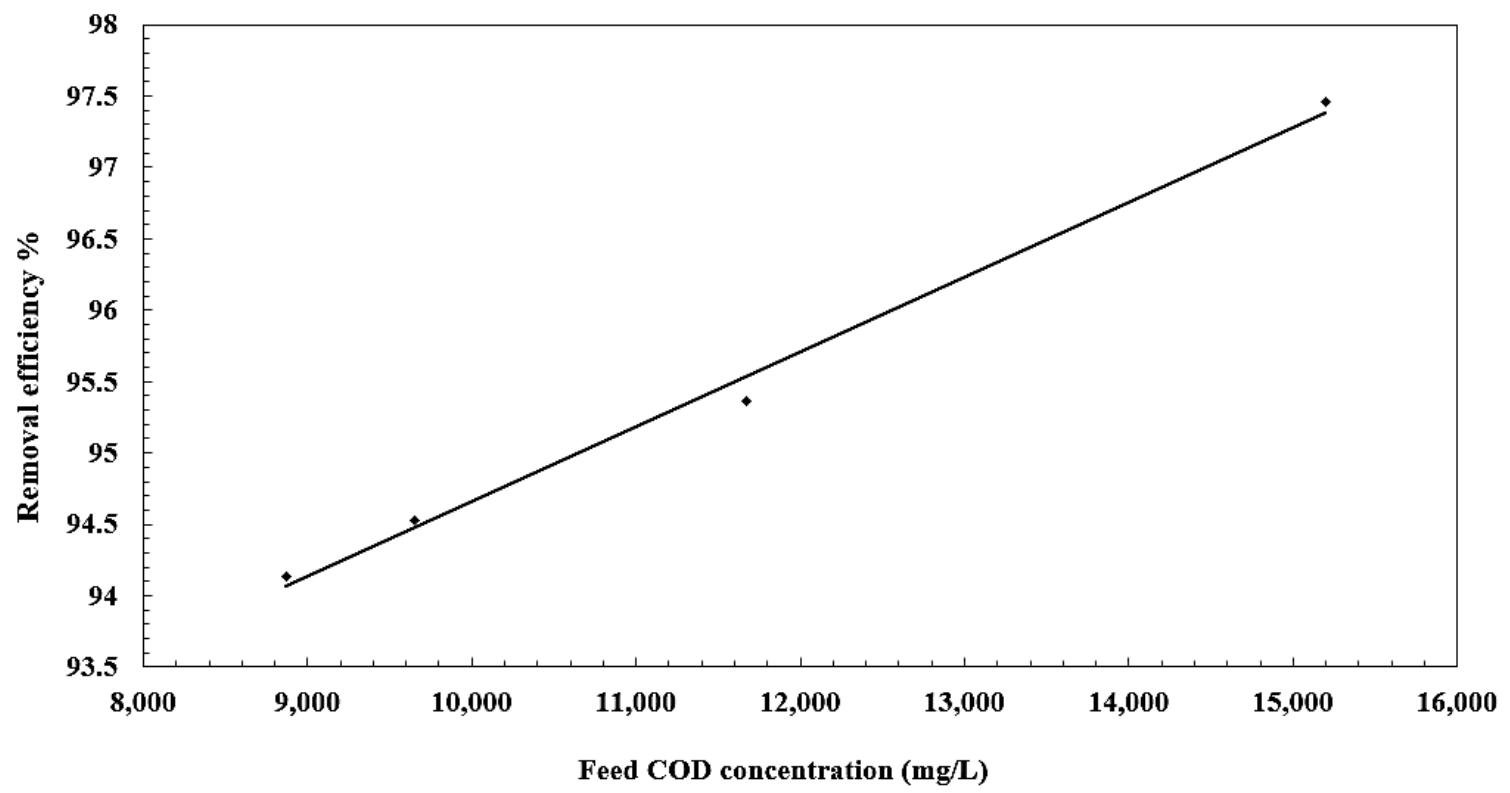

Figure 12. Effect of feed concentration on removal efficiency.

\subsection{Effect of Adsorption Pretreatment unit on Membrane Filtration Performance}

Permeate flux decreased as a result of membrane fouling and concentration polarization. Using activated carbon pretreatment unit led to a decrease in suspended solids' load on membrane filtration. Oil removal improved to $99.9 \%$ in the presence of a pre-treatment unit as listed in Table 4 . Oil concentration in terms of COD in the permeate stream was less than $100 \mathrm{mg} / \mathrm{L}$ which meets the national discharge standards of wastewater.

Table 4. Effect of pretreatment on permeate characteristics.

\begin{tabular}{cccc}
\hline $\begin{array}{c}\text { Oil Concentration of } \\
\text { Feed }(\mathbf{m g} / \mathrm{L})\end{array}$ & $\begin{array}{c}\text { Oil Concentration of } \\
\text { Permeate before } \\
\text { Pretreatment } \\
\mathbf{( m g / L )}\end{array}$ & $\begin{array}{c}\text { Oil Concentration of } \\
\text { Permeate after } \\
\text { Pretreatment and RO } \\
\mathbf{( m g / L )}\end{array}$ & Rejection \% \\
\hline 5653 & 105 & 4.8 & 99.91 \\
4343 & 219 & 5.3 & 99.87 \\
3591 & 186 & 4.3 & 99.88 \\
3299 & 235 & 3.2 & 99.90 \\
\hline
\end{tabular}

\section{Conclusions}

The reverse osmosis thin film composite membrane showed good results in the treatment of oily wastewater produced from the edible oil industry. Removal of turbidity, COD, and oil removal at fixed flux was achieved using RO and an adsorption unit hybrid system. An activated carbon unit as a pretreatment unit showed better efficiency and higher permeate flux. Membrane filtration using a reverse osmosis membrane was conducted to remove edible oil and suspended solids from oily wastewater. An RO membrane was characterized using FTIR, SEM, contact angle, mechanical analysis, and TGA. The PA-TFC membrane showed a promising separation process for treatment of wastewater effluent from edible oil. Significant removal of COD and turbidity can be accomplished using RO. Higher flux and better membrane performance can be achieved using an $\mathrm{RO}$ membrane filtration coupled with an activated carbon unit. A concentration of oil up to $6000 \mathrm{mg} / \mathrm{L}$ can be effectively improved to $99.9 \%$.

Author Contributions: Conceptualization, methodology S.E., R.A.M.; formal analysis, investigation M.H.E., S.A.-H. and Y.E.; data curation, M.B., Y.E.; writing—original draft preparation, S.E. and S.A.-H.; writing-review 
and editing, M.S., M.B.; supervision, R.A.M, M.H.E. and M.Y.S. All authors have read and agreed to the published version of the manuscript.

Funding: This research received no external funding.

Conflicts of Interest: The authors declare no conflict of interest.

\section{References}

1. Lee, Z.S.; Chin, S.Y.; Lim, J.W.; Witoon, T.; Cheng, C.K. Treatment technologies of palm oil mill effluent (POME) and olive mill wastewater (OMW): A brief review. Environ. Technol. Innov. 2019, 15, 100377. [CrossRef]

2. Talha, A.; Belwal, T.; Li, L.; Ramola, S.; Aadil, R.M.; Xu, Y.; Luo, Z. Utilization of wastewater from edible oil industry, turning waste into valuable products: A review. Trends Food Sci. Technol. 2020, 99, 21-33.

3. Ahmad, N.A.; Goh, P.S.; Abdul Karim, Z.; Ismail, A.F. Thin film composite membrane for oily waste water treatment: Recent advances and challenges. Membranes 2018, 8, 86. [CrossRef]

4. Daramola, M.O.; Hlanyane, P.; Sadare, O.O.; Oluwasina, O.O.; Iyuke, S.E. Performance of carbon nanotube/polysulfone (CNT/Psf) composite membranes during Oil-water mixture separation: Effect of CNT dispersion method. Membranes 2017, 7, 14. [CrossRef] [PubMed]

5. Kale, V.; Katikaneni, S.S.P.; Cheryan, M. Deacidification of ricebran oil by solvent extraction and membrane technology. JAOCS 1999, 76, 723. [CrossRef]

6. Han, M.; Zhang, J.; Chu, W.; Chen, J.; Zhou, G. Research Progress and Prospects of Marine Oily Wastewater Treatment: A Review. Water 2019, 11, 2517. [CrossRef]

7. Shao, S.; Li, Y.; Lü, T.; Qi, D.; Zhang, D.; Zhao, H. Removal of Emulsified Oil from Aqueous Environment by Using Polyvinylpyrrolidone-Coated Magnetic Nanoparticles. Water 2019, 11, 1993. [CrossRef]

8. Capodici, M.; Cosenza, A.; Di Trapani, D.; Mannina, G.; Torregrossa, M.; Viviani, G. Treatment of Oily Wastewater with Membrane Bioreactor Systems. Water 2017, 9, 412. [CrossRef]

9. Song, Y.C.; Kim, I.S.; Koh, S.C. Demulsification of oily wastewater througha synergistic effect of ozone and salt. Water Sci. Technol. 1998, 38, 247-253. [CrossRef]

10. Liu, Z.; Qin, D.; Zhao, J.; Feng, Q.; Li, Z.; Bai, H.; Sun, D.D. Efficient Oil/Water Separation Membrane Derived from Super-Flexible and Superhydrophilic Core-Shell Organic/Inorganic Nanofibrous Architectures. Polymers 2019, 11, 974. [CrossRef]

11. Deng, S.; Yu, G.; Jiang, Z.; Zhang, R.; Ting, Y.P. Destabilization of oil droplets in produced water from ASP flooding. Colloid Surf. A Physicochem. Eng. Aspects 2005, 252, 113-119. [CrossRef]

12. Zouboulis, A.I.; Avranas, A. Treatment of oil-in-water emulsions by coag-ulation and dissolved-air flotation. Colloid Surf. A Physicochem. Eng. Asp. 2000, 172, 153-161. [CrossRef]

13. Chen, G. Electrochemical technologies in wastewater treatment. Sep. Purif. Technol. 2004, 38, 11-41. [CrossRef]

14. Iskandar, M.J.; Baharum, A.; Anuar, F.H.; Othaman, R. Palm oil industry in South East Asia and the effluent treatment technology-A review. Environ. Technol. Innov. 2018, 9, 169-185. [CrossRef]

15. Elhenawy, Y.; Nabil, A.S.; Elminshawy, M.; Bassyouni, A.A.A.; Drioli, E. Experimental and theoretical investigation of a new air gap membrane distillation module with a corrugated feed channel. J. Membr. Sci. 2020, 594, 117461. [CrossRef]

16. Bassyouni, M.; Abdel-Aziz, M.H.; Zoromba, M.S.; Abdel-Hamid, S.M.S.; Drioli, E. A review of polymeric nanocomposite membranes for water purification. J. Ind. Eng. Chem. 2019, 73, 19-46. [CrossRef]

17. Asmaa, E.; Nady, N.; Bassyouni, M.; El-Shazly, A. Metal organic framework based polymer mixed matrix membranes: Review on applications in water purification. Membranes 2019, 9, 88.

18. Ali, I.; Bamaga, O.A.; Gzara, L.; Bassyouni, M.; Abdel-Aziz, M.H.; Soliman, M.F.; Drioli, E.; Albeirutty, M. Assessment of blend PVDF membranes, and the effect of polymer concentration and blend composition. Membranes 2018, 8, 13. [CrossRef]

19. Soliman, M.F.; Abdel-Aziz, M.H.; Bamaga, O.A.; Gzara, L.; Sharaf, F.; Al-Sharif, M.; Bassyouni, Z.; Ahmad, R. Performance evaluation of blended PVDF membranes for desalination of seawater RO brine using direct contact membrane distillation. Desalin. Water Treat. 2017, 63, 6. [CrossRef] 
20. Maddah, H.A.; Alzhrani, A.S.; Almalki, A.M.; Bassyouni, M.; Abdel-Aziz, M.H.; Zoromba, M.; Shihon, M.A. Determination of the treatment efficiency of different commercial membrane modules for the treatment of groundwater. J. Mater. Environ. Sci. 2017, 8, 2006-2012.

21. Hemmati, M.; Rekabdar, F.; Gheshlaghi, A.; Salahi, A.; Mohammadi, T. Effects of air sparging, cross flow velocity and pressure on permeation flux enhancement in industrial oily wastewater treatment using microfi ltration. Desalin. Water Treat. 2012, 39, 33-40. [CrossRef]

22. Wu, C.; Li, A.; Li, L.; Zhang, L.; Wang, H.; Qi, X.; Zhang, Q. Treatment of oily water by a poly (vinyl alcohol) ultrafiltration membrane. Desalination 2008, 225, 312-321. [CrossRef]

23. Masoudnia, K.; Raisi, A.; Aroujalian, A.; Fathizadeh, M. A hybrid microfiltra-tion/ultrafiltration membrane process for treatment of oily wastewater. Desalin. Water Treat. 2005, 55, 901-912. [CrossRef]

24. Pulido, J.M.O. A review on the use of membrane technology and fouling control for olive mill wastewater treatment. Sci. Total Environ. 2016, 563, 664-675. [CrossRef] [PubMed]

25. Gryta, M.; Karakulski, K.; Morawski, A.W. Purification of oily wastewater by hybrid UF/MD. Water Res. 2001, 35, 3665-3669. [CrossRef]

26. Yan, L.; Hong, S.; Li, M.L.; Li, Y.S. Application of the $\mathrm{Al}_{2} \mathrm{O}_{3}-\mathrm{PVDF}$ nanocompositetubular ultrafiltration (UF) membrane for oily wastewater treatment and its antifouling research. Sep. Purif. Technol. 2009, 66, 347-352. [CrossRef]

27. Kaur, H.; Bulasara, V.K.; Gupta, R.K. Influence of $\mathrm{pH}$ and temperature ofdip-coating solution on the properties of cellulose acetate-ceramic compositemembrane for ultrafiltration. Carbohydr. Polym. 2018, 195, 613-621. [CrossRef]

28. Schwarze, M. Micellar-enhanced ultrafiltration (MEUF)—State of the art. Environ. Sci. Water Res. Technol. 2017, 3, 598-624. [CrossRef]

29. Gholamzadeh, N.; Peyravi, M.; Jahanshahi, M. Study on olive oil wastewater treatment: Nanotechnology impact. J. Water Environ. Nanotechnol. 2016, 1, 145-161.

30. Wu, P.; Jiang, L.Y.; He, Z.; Song, Y. Treatment of metallurgical industrywastewater for organic contaminant removal in China: Status, challenges, andperspectives. Environ. Sci. Water Res. Technol. 2017, 3, 1015-1031. [CrossRef]

31. Bassyouni, M.; Mansi, A.E.; Elgabry, A.; Ibrahim, B.A.; Kassem, O.A.; Alhebeshy, R. Utilization of carbon nanotubes in removal of heavy metals from wastewater: A review of the CNTs' potential and current challenges. Appl. Phys. A 2020, 126, 38. [CrossRef]

32. Gao, W.J.; Leung, K.T.; Qin, W.S.; Liao, B.Q. Effects of temperature andtemperature shock on the performance and microbial community structureof a submerged anaerobic membrane bioreactor. Bioresour. Technol. 2011, 102, 8733-8740. [CrossRef] [PubMed]

33. Xiangli, Q.; Zhenjia, Z.; Nongcun, W.; Wee, V.; Low, M.; Loh, C.S.; Hing, N.T. Coagulation pretreatment for a large-scale ultrafiltration process treating water from the Taihu River. Desalination 2008, 230, 305-313. [CrossRef]

34. Ahmed, Y.; Yaakob, Z.; Akhtar, P.; Sopian, K. Production of biogas and performance evaluation of existing treatment processes in palm oil mill effluent (POME). Renew. Sustain. Energy Rev. 2015, 42, 1260-1278. [CrossRef]

35. Louhich1, G.; Bousselm1, L.; Ghrab1, A.; Khoun1, I. Process optimization via response surface methodology in the physico-chemical treatment of vegetable oil refinery wastewater. Environ. Sci. Pollut. Res. 2018, 26, 18993-19011.

36. Šereš, Z.; Simović, D.Š.; Dokić, L.; Giorno, L.; Pajin, B.; Hodur, C.; Maravić, N. Edible oilindustry wastewater treatment by microfiltration with ceramic membrane. Int. J. Civ. Mech. Eng. 2016, 10, 410-413.

37. Stoller, M.; Vilardia, G.; Di, L.; Palmaa, A.C. Treatment of olive oil processing wastewater by ultrafiltration, nanofiltration, reverse osmosis and biofiltration. Chem. Eng. 2016, 47, 409-414.

38. Azmi, N.S.; Yunos KF, M.; Baharuddin, A.S.; Dom, Z.M. The effect of operating parameters on ultrafiltration and reverse osmosis of palm oil mill effluent for reclamation and reuse of water. BioResources 2012, 8, 76-87. [CrossRef]

39. Azmi, N.A.; Yunos, K.M.; Zakaria, R. Application of sandwich membrane for the treatment of palm oil mill effluent (POME) for water reuse. Procedia Eng. 2012, 44, 1980-1981. [CrossRef]

40. Košutić, K.; Dolar, D.; Kunst, B. On experimental parameters characterizing the reverse osmosis and nanofiltration membranes' active layer. J. Membr. Sci. 2006, 282, 109-114. 
41. Khouni, I.; Louhichi, G.; Ghrabi, A.; Moulin, P. Efficiency of a coagulation/flocculation-membrane filtration hybrid process for the treatment of vegetable oil refinery wastewater for safe reuse and recovery. Process Saf. Environ. Prot. 2020, 135, 323-341. [CrossRef]

42. Zhao, F.-B.; Yu, Z.-J.; Park, H.-D.; Liu, X.-Y.; Song, X.-R.; Li, Z.-S. Polyvinylchloride ultrafiltration membranes modified with different $\mathrm{SiO}_{2}$ particles and their antifouling mechanism for oil extraction wastewater. J. Environ. Eng. 2015, 141, 04015009. [CrossRef]

43. Chakrabarty, B.; Ghoshal, A.K.; Purkait, M.K. Ultrafiltration of stable oil-in-wateremulsion by polysulfone membrane. J. Membr. Sci. 2008, 325, 427. [CrossRef]

44. Mittal, P.; Jana, S.; Mohanty, K. Synthesis of low-cost hydrophilic ceramic-polymeric composite membrane for treatment of oily wastewater. Desalination 2011, 282, 54-62. [CrossRef]

45. He, Z.; Miller, D.J.; Kasemset, S.; Paul, D.R.; Freeman, B.D. The effect of permeate flux on membrane fouling during microfiltration of oily water. J. Membr. Sci. 2017, 525, 25-34. [CrossRef]

46. Iranizadeh, S.T.; Chenar, M.P.; Mahboub, M.N.; Namaghi, H.A. Preparation and characterization of thin-film composite reverse osmosis membrane on a novel aminosilane-modified polyvinyl chloride support. Braz. J. Chem. Eng. 2019, 36, 251-264. [CrossRef]

47. Yee, T.L.; Rathnayake, T.; Visvanathan, C. Performance Evaluation of a Thermophilic Anaerobic Membrane Bioreactor for Palm Oil Wastewater Treatment. Membranes 2019, 9, 55. [CrossRef]

48. Al-Ani, F.H.; Alsalhy, Q.F.; Raheem, R.S.; Rashid, K.T.; Figoli, A. Experimental Investigation of the Effect of Implanting $\mathrm{TiO}_{2}$-NPs on PVC for Long-Term UF Membrane Performance to Treat Refinery Wastewater. Membranes 2020, 10, 77. [CrossRef]

49. Vu, A.; Mark, N.S.; Ramon, G.Z.; Qian, X.; Sengupta, A.; Wickramasinghe, S.R. Oil Deposition on Polymer Brush-Coated NF Membranes. Membranes 2019, 9, 168. [CrossRef]

(C) 2020 by the authors. Licensee MDPI, Basel, Switzerland. This article is an open access article distributed under the terms and conditions of the Creative Commons Attribution (CC BY) license (http://creativecommons.org/licenses/by/4.0/). 